\title{
Innovative therapeutic concepts of progressive multifocal leukoencephalopathy
}

\author{
Nora Möhn ${ }^{1} \cdot$ Lea Grote-Levi ${ }^{1}$. Franziska Hopfner ${ }^{1}$ - Britta Eiz-Vesper ${ }^{2} \cdot$ Britta Maecker-Kolhoff $^{3}$. Clemens Warnke ${ }^{4}$ \\ Kurt-Wolfram Sühs ${ }^{1} \cdot$ Mike P. Wattjes $^{5} \cdot$ Günter U. Höglinger ${ }^{1} \cdot$ Thomas Skripuletz $^{1}$ (1)
}

Received: 3 November 2021 / Revised: 26 December 2021 / Accepted: 27 December 2021 / Published online: 7 January 2022

(C) The Author(s) 2022

\begin{abstract}
Progressive multifocal leukoencephalopathy (PML) is an opportunistic viral disease of the brain-caused by human polyomavirus 2. It affects patients whose immune system is compromised by a corresponding underlying disease or by drugs. Patients with an underlying lymphoproliferative disease have the worst prognosis with a mortality rate of up to $90 \%$. Several therapeutic strategies have been proposed but failed to show any benefit so far. Therefore, the primary therapeutic strategy aims to reconstitute the impaired immune system to generate an effective endogenous antiviral response. Recently, antiPD-1 antibodies and application of allogeneic virus-specific T cells demonstrated promising effects on the outcome in individual PML patients. This article aims to provide a detailed overview of the literature with a focus on these two treatment approaches.
\end{abstract}

Keywords Progressive multifocal leukoencephalopathy · Allogeneic virus-specific T cells · Anti-PD-1-antibodies · Immunosuppression · Immune reconstitution

\section{Background}

\section{Introductory remarks}

Progressive multifocal leukoencephalopathy (PML) is an opportunistic infection of the brain caused by the human polyomavirus 2 (HPyV-2) (previously known as: JC polyomavirus). Overall, PML is associated with severe disability and a relatively high mortality [1]. Infection with HPyV-2 usually occurs during childhood, though the proportion of seropositive persons in the population increases with age,

Thomas Skripuletz

Skripuletz.Thomas@mh-hannover.de

1 Department of Neurology, Hannover Medical School, Carl-Neuberg-Str. 1, 30625 Hannover, Germany

2 Institute of Transfusion Medicine and Transplant Engineering, Hannover Medical School, Hannover, Germany

3 Department of Pediatric Hematology and Oncology, Hannover Medical School, Hannover, Germany

4 Department of Neurology, University of Cologne, Cologne, Germany

5 Department of Diagnostic and Interventional Neuroradiology, Hannover Medical School, Hannover, Germany reaching approximately $60-80 \%$ in 70 -year-olds $[2,3]$. The rate is also highly dependent on the serological test applied, with different groups reporting highly variable seropositivity rates. HPyV-2 usually leads to an asymptomatic, lifelong persistent and latent infection in the general population. However, in patients with long-lasting and profound impairment of cellular immunity, HPyV-2 can reactivate from latency or persistent asymptomatic infection and undergo intra-individually acquired viral genomic rearrangements leading to neuroinvasion and lytic infection of white matter (predominantly oligodendrocytes) and neuronal cells in the brain $[4,5]$. The in vivo diagnosis of PML is based on the clinical presentation, brain imaging findings (preferably magnetic resonance imaging, MRI) and the detection of the virus in the cerebrospinal fluid (CSF) by polymerase chain reaction (PCR) [6]. The fact that there is no animal model for PML and that HPyV-2 is difficult to grow in culture remains a major challenge for the development of antiviral therapeutic strategies against HPyV-2. To date, direct antiviral therapeutics such as cidofovir, mirtazapine, cytarabine, or mefloquine have failed to improve survival or reduce disability in PML patients [28-31]. Basically, the key to successful treatment of PML is restoring the functions of the immune system (Fig. 1). The aim of this review is to present 
Fig. 1 Overview of causes of progressive multifocal leukoencephalopathy and potential innovative treatment options. AIDS, acquired immunodeficiency syndrome; PD-1, programmed cell death protein

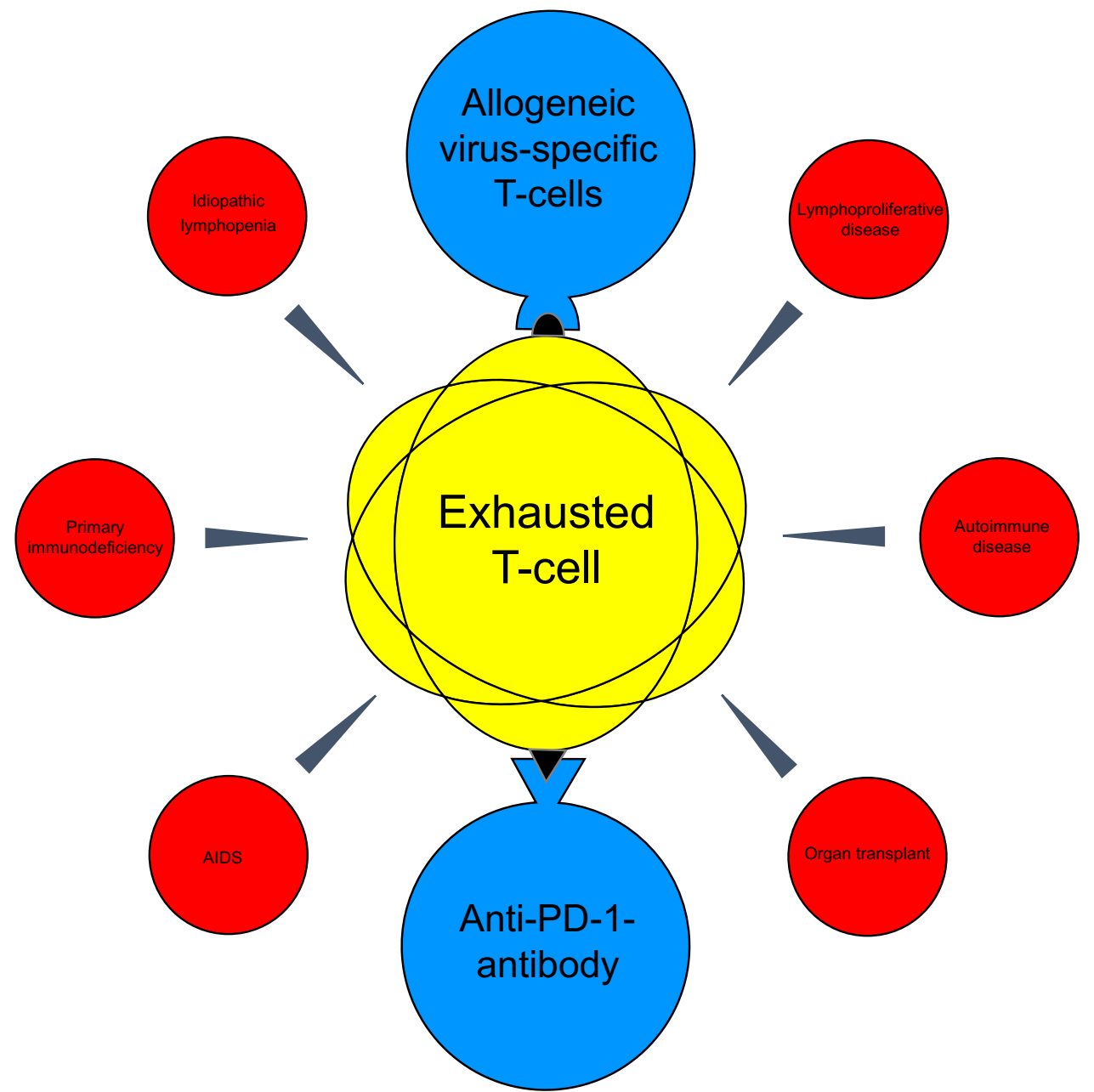

different therapeutic strategies for the management of PML. In addition to the use of interleukins, the treatment of PML with anti-PD-1 antibodies and allogeneic virus-specific $\mathrm{T}$ cells will be characterized in particular. For this purpose, all cases and case series published to date on this topic have been summarized.

\section{Immunological mechanisms and causative factors of PML}

Because most adults are exposed to HPyV-2 in childhood, HPyV-2-specific antibodies, and memory $\mathrm{T}$ cells are found in their blood. In patients with a human polyomavirus 1 (HPy V-1) (formerly known as: BK virus) infection, a close relative of HPyV-2 sharing immunologically significant epitopes, it has been shown that an increase in antibody titers is associated with a reduction in viral load $[7,8]$. Although these antibodies can effectively control viremia, they cannot control polyomavirus-associated complications. In contrast, the presence of cytotoxic $(\mathrm{CD} 8+) \mathrm{T}$ cells has been shown to correlate positively with a beneficial clinical course of PML [9]. Thus, it is reasonable that an impaired T-cell immune response due to underlying immunosuppressive disease entities or therapy increases the risk of PML. The role of B cells in the pathogenesis of PML is rather unclear. Functional $B$ cells are necessary for adequate viral defense and the risk for PML is quite high, especially in chronic lymphocytic leukemia (CLL) and other B-cell-associated lymphoproliferative disorders. This might be due to the fact that certain B-cell transcription factors (especially Spi-B) promote not only B-cell differentiation but also HPyV-2 replication [10]. In general, the causes of PML can be divided into three major subgroups. The first group consists of patients with human immunodeficiency virus (HIV)-infection whose PML risk is due to the underlying disease alone. At the height of the acquired immunodeficiency syndrome (AIDS) pandemic, approximately $5 \%$ of HIV-positive patients developed PML [11]. After the introduction of highly active antiretroviral therapy, both the number of HIV patients developing PML and the mortality of PML in these patients decreased significantly [12]. The risk of developing PML is highly dependent on the number of CD4+ T cells and current overall incidence 
rate amounts to about $1 / 1000$ person-years [1, 13-15]. The second group includes patients whose PML risk is due to both their underlying disease and its therapy. Particularly those affected by a lymphoproliferative disease should be mentioned here, since both the disease itself as well as its therapy severely compromises the immune system. To date, PML patients with an underlying malignant hematologic disease have the worst outcome. Mortality in individual studies of smaller size is about $90 \%$ and many patients die within the first 2 months after diagnosis [16-19]. The last group comprises patients who receive immunosuppressive therapy, e.g. due to an autoimmune disease. In this context, it should be mentioned that the incidence of monoclonal antibody therapyrelated PML has substantially increased in recent years. The best-known example of such an agent certainly is the anti-alfa4-integrin antibody natalizumab, which was designed to prevent the migration of leukocytes into the CNS and is approved for the treatment of highly active relapsing multiple sclerosis. Since its approval in 2004, 839 cases of PML have been reported to date (as of September 2020, www.tysabri.de, accessed 07/10/2021), with risk correlating with duration of treatment and blood HPyV-2 antibody index values (quantifies antibody reactivity relative to a reference sera) [20]. The mortality of natalizumab-related PML is approximately $20 \%$ to $23 \%$ [21-23], but survivors largely carry severe or at least moderate disability [22]. Prognosis in this group of patients largely depends on the time of diagnosis and the extent of lesion burden on MRI at the time of PML diagnosis. Patients who were not symptomatic when PML is diagnosed and patients with less extensive disease on MRI at diagnosis tend to have a better prognosis with better survival rates and less functional disability [23-25]. A special feature of this group of natalizumab-treated patients is that they are particularly prone to develop a so-called PML-immune reconstitution inflammatory syndrome (PML-IRIS). This phenomenon is characterized by an excessive inflammatory reaction leading to paradoxical worsening after implementing immune system restoration. It can occur in all PML patients in principle, but is particularly well characterized in natalizumab-associated PML [21].

Patients with other autoimmune diseases are also increasingly treated with novel immunomodulatory therapies, especially with monoclonal antibodies such as rituximab or infliximab [26]. The rate of PML cases in these patients is significantly lower than in those with lymphoproliferative diseases. Nevertheless, the risk of PML occurrence must also be considered here [27], especially since the use of such therapies will certainly continue to increase in the future. It should be noted that in this last group of patients, treatment suspension can help in improving PML prognosis while worsening the underlying disease.

\section{Use of interleukins for the treatment of PML}

Several studies described the use of interleukins (interleukin-2 and interleukin-7) in PML to reconstitute the immune response. As a trophic factor for lymphocytes, interleukin-2 (IL-2) is required for the establishment and maintenance of adaptive T-cell responses; however, IL-2 is also critical for immune dysregulation through its effect on regulatory $\mathrm{T}$ cells [32]. For example, disruption of IL-2 production after stem cell transplantation appears to lead to a deficiency in cell-mediated immunity and thus to an increased risk of opportunistic infections in stem cell transplanted patients [33]. It is, therefore, not surprising that the positive reports on the use of IL-2 in PML are particularly from patients after stem cell transplantation. In addition, other previously used PML therapies such as cytarabine could not be used because of the risk of cytopenias [34, 35].

There are a total of five case reports on the use of IL-2 in patients with underlying hematologic disease and PML. Two cases received a combination treatment of IL-2 and pembrolizumab. All affected individuals had in common that their underlying disease had led to a partly pronounced lymphocytopenia as the cause of PML. They all benefited from treatment and showed long-term improvement of their neurological symptoms [36-39]. A single publication can be found that addressed IL-2 therapy for natalizumabassociated PML. A 51-year-old female patient with relapsing-remitting multiple sclerosis developed a novel motor aphasia three years after initiation of natalizumab therapy and was diagnosed with PML. Since the symptoms were progressive after plasmapheresis and intravenous immunoglobulins, a therapy with subcutaneous IL-2 was initiated, under which the patient's clinical symptoms improved in the long term and the viral load in the CSF decreased [40].

A total of seven case reports on the use of recombinant interleukin-7 (IL-7) in PML have been published. Each of the patients had $(\mathrm{CD} 4+)$ lymphopenia as the precipitating cause of PML, either idiopathic $(n=3)$ or due to an underlying disease elsewhere (sarcoidosis $(n=1)$, HIV infection $(n=1)$, hematologic disease $(n=2))$. IL-7 therapy was administered either intramuscularly or subcutaneously, and in all cases, there was both an increase in CD4+cells and long-term improvement in neurological symptoms [41-47].

In addition, subcutaneous IL-7 was combined with vaccination against the JCV VP1 protein to target PML. Two patients were treated this way. Both showed an increase in JCV VP1-specific CD4+ T cells and a long-term stabilization or slight improvement of PML-associated symptoms [48]. Another paper by Patel and colleagues described the application of multiple PML therapeutics in a patient with 
CD4+ lymphopenia. In addition to cidofovir, risperidone, and mefloquine, IL-7 and CMX001, an investigational oral agent, were used [49]. The patient benefited from the treatment, but which therapeutic agent was the possibly decisive one remained unanswered. In summary, the results for the treatment of PML with interleukins are promising especially if PML is based on CD4+ lymphopenia. Since data remain sparse and most case reports are several years old, it is very encouraging that a recent pilot study (NCT04781309) is investigating the value of recombinant IL-7 for the treatment of lymphopenia in PML patients.

Furthermore, in recent years, two modern therapeutic approaches to PML have emerged as promising candidates for the treatment of PML in small case series and single case reports (Table 1). They are both based on the activation of the endogenous immune system and will be characterized in more detail below.

\section{Anti-PD-1-antibodies}

The primary therapeutic scope of anti-programmed death (PD)-1 antibodies such as nivolumab or pembrolizumab are oncological diseases. The pharmacodynamic principle of activating CD8 $+\mathrm{T}$ cells to generate a potent antitumor response has revolutionized cancer therapy. After the approval for indications such as metastatic malignant melanoma or non-small cell lung cancer, the use of PD-1 antibodies in chronic viral infections has been suggested. Over time, increasing evidence suggested that the PD-1/

Table 1 Overview of published case reports on innovative immunotherapy for progressive multifocal leukoencephalopathy (PML)

\begin{tabular}{|c|c|c|c|c|c|}
\hline & Therapy & $\begin{array}{l}\text { Median } \\
\text { patient's age } \\
\text { (years) }\end{array}$ & Underlying diseases & Outcome & Adverse events \\
\hline \multirow{11}{*}{$\begin{array}{l}\text { Anti-PD- } \\
\text { 1-anti- } \\
\text { bodies }\end{array}$} & \multirow[t]{5}{*}{ Nivolumab $(n=9)$} & \multirow[t]{5}{*}{$53(42-73)$} & $\begin{array}{l}\text { Lymphoproliferative disease } \\
\qquad(n=6)\end{array}$ & $\begin{array}{l}\text { 4/9 (44\%) Improvement of } \\
\text { symptoms }\end{array}$ & PML-IRIS $(n=3)$ \\
\hline & & & Idiopathic lymphopenia $(n=1)$ & $\begin{array}{l}\text { 2/9 (22\%) Stabilization of } \\
\text { symptoms }\end{array}$ & Arthritis $(n=1)$ \\
\hline & & & $\begin{array}{l}\text { Primary immunodeficiency } \\
\quad(n=2)\end{array}$ & 3/9 (33\%) Death & Myositis $(n=2)$ \\
\hline & & & & & Parkinsonism $(n=1)$ \\
\hline & & & & & Colitis/Hepatitis $(n=1)$ \\
\hline & \multirow[t]{6}{*}{ Pembrolizumab $(n=21)$} & \multirow[t]{6}{*}{$68(31-78)$} & $\begin{array}{l}\text { Lymphoproliferative disease } \\
\qquad(n=11)\end{array}$ & $\begin{array}{l}\text { 7/21 (33\%) Improvement of } \\
\text { symptoms }\end{array}$ & PML-IRIS $(n=4)$ \\
\hline & & & AIDS $(n=3)$ & $\begin{array}{l}6 / 21(29 \%) \text { Stabilization of } \\
\text { symptoms }\end{array}$ & Exanthema $(n=2)$ \\
\hline & & & Idiopathic lymphopenia $(n=2)$ & $\begin{array}{l}1 / 21(5 \%) \text { Worsening of } \\
\text { symptoms }\end{array}$ & Psoriasis flare $(n=1)$ \\
\hline & & & $\begin{array}{l}\text { Primary immunodeficiency } \\
\quad(n=3)\end{array}$ & $7 / 21(33 \%)$ Death & Diarrhea $(n=1)$ \\
\hline & & & Autoimmune disease $(n=1)$ & & \\
\hline & & & Unknown $(n=1)$ & & \\
\hline \multirow{10}{*}{$\begin{array}{l}\text { Allogeneic } \\
\text { virus- } \\
\text { specific } \\
\text { T cells }\end{array}$} & \multirow[t]{7}{*}{ HPyV-1-specif. $(n=19)$} & \multirow[t]{7}{*}{$57(19-73)$} & $\begin{array}{l}\text { Lymphoproliferative disease } \\
\qquad(n=11)\end{array}$ & $\begin{array}{l}10 / 19(53 \%) \text { Improvement of } \\
\text { symptoms }\end{array}$ & PML-IRIS $(n=2)$ \\
\hline & & & $\begin{array}{l}\text { Primary immunodeficiency } \\
\quad(n=2)\end{array}$ & $\begin{array}{l}\text { 4/19 (21\%) Stabilization of } \\
\text { symptoms }\end{array}$ & \\
\hline & & & Autoimmune disease $(n=2)$ & $5 / 19(26 \%)$ Death & \\
\hline & & & $\operatorname{AIDS}(n=1)$ & & \\
\hline & & & Tumor disease $(n=1)$ & & \\
\hline & & & Hepatitis B and D $(n=1)$ & & \\
\hline & & & $\begin{array}{l}\text { Immunodeficiency }+ \text { hemolytic } \\
\text { anemia }(n=1)\end{array}$ & & \\
\hline & \multirow[t]{3}{*}{ HPyV-2-specif. $(n=10)$} & \multirow[t]{3}{*}{$57(17-70)$} & $\begin{array}{l}\text { Lymphoproliferative disease } \\
\qquad(n=9)\end{array}$ & $\begin{array}{l}\text { 3/10 }(30 \%) \text { Improvement of } \\
\text { symptoms }\end{array}$ & PML-IRIS $(n=2)$ \\
\hline & & & \multirow[t]{2}{*}{ Idiopathic lymphopenia $(n=1)$} & $\begin{array}{l}\text { 3/10 (30\%) Stabilization of } \\
\text { symptoms }\end{array}$ & \\
\hline & & & & 4/10 (40\%) Death & \\
\hline
\end{tabular}

IRIS, immune reconstitution inflammatory syndrome; PD-1, programmed cell death protein 1 
PD-L1 axis is upregulated during acute viral infections to protect surrounding tissues from an exuberant immune response [50]. However, if the virus cannot be eliminated and a chronic viral infection develops, this mechanism causes exhaustion of the antiviral immune response (socalled exhausted $\mathrm{T}$ cells), particularly the CD8+ T cells [50]. The hypothesis that such T-cell exhaustion may also play a role in PML has led to the attempt of using antiPD-1 antibodies in this chronic viral disease [51]. In addition, increased PD-1 expression was detected not only on $\mathrm{T}$ cells in the blood and CSF of PML patients, but also on intralesional T cells in the CNS. Simultaneously, increased PD-L1 expression was shown on macrophages within PML lesions, highlighting the relevance of the PD-1/PD-L1 axis in PML [52]. The first paper on the use of pembrolizumab and nivolumab in PML was published in 2019. Eight PML patients with different underlying diseases (HIV infection $(n=2)$, (non)-Hodgkin's lymphoma $(n=4)$, idiopathic lymphopenia $(n=2))$ were treated with pembrolizumab at a dose of $2 \mathrm{mg}$ per $\mathrm{kg}$ body weight every $4-6$ weeks. A maximum of three doses were administered in total. During therapy, two patients experienced improvement of neurological symptoms, stabilization of symptoms occurred in four cases, and two patients did not benefit from therapy. In those patients, worsening of clinical symptoms in combination with increased lesion load on brain MRI and HPyV-2 viral load in CSF was observed [52]. It should be noted that no PML-IRIS occurred in any case. The authors reasoned that this was due to the persistence of lymphopenia in all patients beyond pembrolizumab therapy.

In addition to the eight cases mentioned above, additional 13 individual case reports and two smaller case series (totaling 22 additional patients) were published during the course of the study on the use of PD-1 inhibitors in PML [53-64]. Eight of the 13 individual case reports described the use of pembrolizumab, and the remaining five publications used nivolumab. Clinical improvement was achieved in 7 of 13 cases (54\%), 2 patients (15\%) stabilized, and $4(31 \%)$ died due to disease progression. For more clinical and demographic details regarding the patients treated see Table S1 (supplementary material).

A recent case series by Roos-Weil and colleagues in 2021 described six PML patients treated with anti-PD-1 antibodies (nivolumab $(n=4)$, pembrolizumab $(n=2)$ ). The cause of PML was a hematologic malignancy in four cases, one patient suffered from a primary immunodeficiency, and one case was on immunosuppressive therapy for myasthenia gravis. Within the long-term follow-up 14-33 months after initiation of anti-PD-1 treatment, three of the six patients were still alive, one with clinical improvement and two with stabilization of symptoms. Three patients died despite treatment [65].
We recently published a case series describing three PML patients with underlying hematological diseases. One patient with long-standing Waldenstrom's disease showed marked improvement in his PML-associated symptoms during therapy with pembrolizumab and ultimately became symptomfree, whereas the other two patients suffered a fatal course of PML despite anti-PD-1 therapy. Both had been previously treated with rituximab and had no detectable CD20- and CD19-positive cells in their blood at the time of diagnosis [66].

Formally, no causal conclusions can be drawn from the few publications with a very heterogeneous patient group. What can be concluded, however, is that in addition to the initial positive case reports, there was worsening of PML symptoms and even death of patients despite the use of an anti-PD-1 antibody in 33\% and 38\% of the cases, respectively (Table 1). The level of HPyV-2 viral load, PD-1 expression of $\mathrm{T}$ cells, and the number of HPyV-2-specific $\mathrm{CD} 8+$ and $\mathrm{CD} 4+\mathrm{T}$ cells are discussed as possible factors influencing the success of the treatment [67]. In addition, the T-cell phenotype seems to play an important role. Pawlitzki and colleagues observed that in a PML patient with fatal disease progression receiving pembrolizumab therapy (13th individual case report), the proportion of Ki67+PD-1+CD45RA- memory T cells, so-called terminally exhausted $\mathrm{T}$ cells, increased significantly [68]. Thus, characterization of immune cell subtypes in PML patients will be of great importance for future therapeutic decisions and prognostic assessments.

In addition, a single case report should be mentioned in which the authors postulated PML as a consequence of therapy with nivolumab. A 54-year-old patient with refractory Hodgkin lymphoma was treated with nivolumab for 13 months after multiple high-dose chemotherapies. In addition, oral steroid therapy for hypocortisolism was ongoing. Thirteen months after initiation of nivolumab therapy, a diagnosis of PML was finally made with increasing neurological deficits, and anti-PD-1 therapy was discontinued due to a presumed causal relationship. Regarding the course, the authors reported that the patient remained alive 5 months after diagnosis, but without relevant improvement in neurological deficits [69]. No other adverse events like this due to nivolumab have been published to date, and it is reasonable to assume that the PML in the aforementioned case was not triggered by anti-PD-1 therapy but was preexisting or due to the underlying malignancy or steroid therapy.

Severe autoimmune phenomena, often been described in oncological patients receiving anti-PD1 therapy [70], have not yet been observed in the treatment of PML. However, in contrast to the initial case series by Cortese et al., PML-IRIS occurred in a total of seven patients in the additional published cases (Table 1). Also, individual less severe autoimmune phenomena, such as single cases of myositis, arthritis 
or colitis were observed as a consequence of anti-PD-1 therapy. Secondary autoimmune phenomena such as pneumonitis, or hypophysitis are common with anti-PD-1 therapy, and neurologists should be vigilant for evidence of such side effects [71]. Especially in patients with pre-existing autoimmune diseases including multiple sclerosis, therapy with nivolumab or pembrolizumab must be discussed very critically. Considering possible autoimmune side effects, which may also affect the CNS in the form of demyelinating inflammation, anti-PD-1 antibody therapy does not seem to be the right option in certain cases.

\section{Allogeneic virus-specific T cells}

Currently, the most promising therapeutic approach may be the use of allogeneic virus-specific T cells. The method has its origins in hematology and has been mainly used in stem cell transplanted patients with Epstein-Barr virus (EBV), cytomegalovirus (CMV), Adenovirus (HAdV) or HPyV-1 infections [8]. Reactivation of HPyV-2 also plays a role in patients after hematopoietic stem cell transplantation, although PML rates are very low compared with hemorrhagic cystitis due to HPyV-1 [72, 73]. The first treatments involving adoptive transfer of virus-specific T cells occurred in the early 1990s [74-76]. Since then, adoptive T-cell therapy has evolved tremendously. Whereas initially peripheral mononuclear cells from seropositive donors were expanded ex vivo in a time-consuming manner, in the course of time it became possible to isolate virus-specific $\mathrm{T}$ cells with major histocompatibility complex (MHC)-multimers in a much more time-effective way [77]. In addition, the risk of graft versus host disease (GVHD) could be minimized by a more targeted selection of virus-specific T cells. Another promising immunotherapeutic approach that has emerged in recent years is the use of HLA-matched T-cell lines from third party donors, which offers the advantage of timely availability of cells for clinical use. The efficacy of this method has been illustrated, particularly for CMV and EBV reactivation after allogeneic stem cell transplantation [78]. In 2011, an Italian group published the case of a young patient with severe chronic GVHD and 5 years of immunosuppressive therapy after allogeneic stem cell transplantation, in whom HPyV-2-specific T cells were used for the first time. At PML diagnosis, the remaining immunosuppression was stopped and antiviral therapy with cidofovir was initiated. In addition, the patient received two infusions of 0.5 and $1.0 \times 10^{6} \mathrm{~T}$ cells from his stem cell donor, respectively, which had been previously coincubated and activated ex vivo with HPyV2-specific proteins [79]. After therapy, there was marked improvement in neurological symptoms, a decrease in lesion burden on brain MRI, and lack of detectability of HPyV-2 DNA in CSF. Importantly, there was no evidence of GvHD.
However, this positive single case report was not followed by further publications on the use of virus-specific T-cell therapy in PML for several years.

In 2018, the therapy with allogeneic $\mathrm{T}$ cells received increased focus as a treatment option for PML. Muftuoglu and colleagues treated three PML patients (32, 35, and 73 years old) with HPyV-1-specific T cells from third party donors, with patients receiving two, three, or four T-cell infusions. Of particular note, two of the three patients suffered from underlying hematological disease (acute myeloid leukemia and polycythaemia vera), which are usually associated with high PML mortality [16-19]. Patient 3 had AIDS due to HIV infection. He had discontinued anti-retroviral therapy 5 years before PML diagnosis because of side effects. All patients experienced a reduction in $\mathrm{HPyV}-2$ viral load in the CSF after the first treatment. With regard to clinical symptoms, two of the three patients experienced a significant reduction or complete remission of neurological symptoms. The third patient, who was 73 years old, experienced stabilization but no improvement of her symptoms and ultimately died under palliative care [80]. The case series suggests that a therapeutic attempt with HPyV-1-specific $\mathrm{T}$ cells may be reasonable in PML and probably has an acceptable safety profile, although proof of efficacy cannot be provided.

As HPyV-2 and HPyV-1 share certain significant epitopes (in particular, the capsid protein VP1 and the so-called large $\mathrm{T}$ antigen (T-Ag), an important regulatory protein of polyomaviruses), there is cross-reactivity for HPyV-2- and HPyV-1-specific T cells [81]. Since the production of HPyV1 -specific $\mathrm{T}$ cells is already established in some manufacturing centers under conditions of "Good Manufacturing Practice (GMP)", their use in PML is obvious.

Encouraged by the work of our colleagues, we also started to treat PML patients with HPyV-1-specific T cells at our center. Recently, the experiences of two successfully treated cases were published [82]. One patient suffered from dermatomyositis as underlying disease, the other patient had developed severe pulmonary fibrosis after successful treatment of Hodgkin's lymphoma, so that she had to undergo lung transplantation with consequent strong immunosuppressive treatment. In comparison to Muftuoglu and colleagues, our clinic does not use preproduced frozen allogeneic peripheral blood mononuclear cells stimulated by HPyV-2 antigens. Rather, we have access to a registry of more than 3500 potential donors. Suitable donors are selected based on the appropriate HLA typing and their T-cell frequency. Direct isolation of antigen-specific T cells is achieved by stimulation with appropriate overlapping peptide mixtures, cytokine capture and magnetic isolation, so that the cells are available after about 16-24 h.

Very recently, the literature on the use of HPyV-1-specific $\mathrm{T}$ cells in PML was extended by another case report and a 
first clinical study. A 57-year-old PML patient with underlying marginal cell lymphoma was initially treated with a total of 10 infusions of pembrolizumab. Because of insufficient reduction of viral load in CSF, the patient additionally received two infusions of $\mathrm{HPyV}$-1-specific $\mathrm{T}$ cells at 7-week intervals [83]. During therapy, there was both a significant reduction in viral load and improvement in neurological symptoms.

A first pilot clinical trial about treatment with HPyV1-specific T cells was presented by Cortese and colleagues in August 2021 [84]. After screening of a total of 26 patients, 12 PML patients were ultimately treated. They received a maximum of three infusions of HPy V-1-specific T cells donated by first-degree relatives. One year after the start of the treatment, seven of the twelve patients were still alive, five patients died of PML. No treatment-associated adverse events were reported. It should be noted that the production time of the final T-cell product in this study amounted to up to 4-6 weeks. Because of the long duration of T-cell production, some individual patients could no longer be included in the study due to symptom exacerbation. The extent to which a longer manufacturing time to the final $\mathrm{T}$-cell product negatively affects patient outcome cannot be conclusively assessed due to limited data.

In addition to HPyV-1 specific therapies, treatment of PML with HPyV-2-specific T cells is also gaining increasing interest. The literature contains a recent single case report and a case series on the use of HPyV-2-specific T cells in PML. In the case of a 59-year-old man with refractory multiple myeloma who had undergone allogeneic stem cell transplantation, HPyV-2-specific T cells were derived from the lymphocytes of the HLA-identical stem cell donor. After termination of the ongoing chemotherapy and subsequent T-cell administration, neurological symptoms stabilized and HPyV-2 was not detected in the cerebrospinal fluid (CSF), whereas there was subtle morphological evidence of an immune reconstitution syndrome. Apart from focal epilepsy secondary to PML, the patient was free of neurological symptoms 12 months after therapy with HPyV-2-specific T cells [85].

In January 2021, an Italian group published a case series on HPyV-2-specific T-cell therapy in nine PML patients, in which cell lines were derived from autologous or allogeneic peripheral blood mononuclear cells by stimulation with protein multimers in a procedure of approximately 4 weeks [86]. Seven of the nine patients suffered from malignant hematologic diseases, six of whom had previously received B-cell depleting therapy (rituximab). Of the nine patients treated, three patients, all of whom had been treated with B-cell depleting therapy as part of their underlying malignant hematologic disease, died as a result of PML. One additional death was attributed to varicella zoster virus (VZV) encephalitis. Two of the surviving patients (each with non-Hodgkin's lymphoma as the underlying disease) had stabilization of neurologic symptoms, and three showed more or less marked improvement of symptoms. In five cases, the HPy V-2-specific cellular immune response was analyzed before and after cell therapy. In four of five patients, there was a relevant increase in interferon-gamma (IFN)-producing $\mathrm{HPyV}$-2-specific $\mathrm{T}$ cells after T-cell application, which in turn correlated with a favorable outcome [86].

\section{Conclusions}

PML is a rare but often fatal opportunistic viral disease of the brain, for which there has been no adequate therapeutic strategy yet. Basically, the outcome of patients depends on how quickly the body's own immune response, which is usually impaired in PML patients, can be restored. The ease with which such immune reconstitution can be achieved depends very much on the underlying disease. Patients with underlying hematological diseases remain particularly problematic, as both the disease itself and its therapy can lead to a significant impairment of the immune system.

The two innovative therapeutic concepts mentioned above show promising results in some cases, although the success of treatment varies considerably between patients, particularly in the case of anti-PD-1 therapy. The therapeutic options for PML described in this article cannot all be applied equally to the different PML subgroups. The primary target group is certainly those patients whose immune response is impaired by the underlying disease and its therapy. In the case of HIV-associated PML, the prognosis can usually be improved with the use of effective antiretroviral therapy alone. If the PML is triggered by an immunosuppressive therapy for the treatment of an autoimmune disease, the termination of this therapy can contribute to the treatment of PML, while at the same time a worsening of the underlying disease can occur. These factors must be considered when selecting a therapeutic regimen for PML. With a low overall number of cases to date, it is not yet possible to draw definitive conclusions regarding the efficacy of the treatment approaches. However, the adverse effects described so far seem to be limited. This is true for antiPD-1 therapy as well as for the use of virus-specific T cells, although secondary autoimmune phenomena must probably be expected, especially with anti-PD-1 therapy. Based on the literature to date, therapy with allogeneic $\mathrm{T}$ cells seems to provide the most promising results in the treatment of PML. The factors for successful therapy, for example the question to what extent a delayed manufacturing time affects the outcome, and whether success can be predicted pre-therapeutically should be the subject of future studies. 
Supplementary Information The online version contains supplementary material available at https://doi.org/10.1007/s00415-021-10952-5.

Author contributions NM, LG-L, and TS had the idea for the article. NM and LG-L performed the literature search and data analysis. The first draft of the manuscript was written by NM. LG-L, FH, BE-V, BM-K, CW, K-WS, MPW, GUH, and TS critically revised the work. All authors read and approved the final manuscript.

Funding Open Access funding enabled and organized by Projekt DEAL. No funds, grants, or other support was received.

\section{Declarations}

Conflicts of interest The authors have no competing interests to declare that are relevant to the content of this article.

Open Access This article is licensed under a Creative Commons Attribution 4.0 International License, which permits use, sharing, adaptation, distribution and reproduction in any medium or format, as long as you give appropriate credit to the original author(s) and the source, provide a link to the Creative Commons licence, and indicate if changes were made. The images or other third party material in this article are included in the article's Creative Commons licence, unless indicated otherwise in a credit line to the material. If material is not included in the article's Creative Commons licence and your intended use is not permitted by statutory regulation or exceeds the permitted use, you will need to obtain permission directly from the copyright holder. To view a copy of this licence, visit http://creativecommons.org/licenses/by/4.0/.

\section{References}

1. Tan CS, Koralnik IJ (2010) Progressive multifocal leukoencephalopathy and other disorders caused by JC virus: clinical features and pathogenesis. Lancet Neurol 9:425-437

2. Egli A, Infanti L, Dumoulin A, Buser A, Samaridis J, Stebler C, Gosert R, Hirsch HH (2009) Prevalence of polyomavirus BK and JC infection and replication in 400 healthy blood donors. J Infect Dis 199:837-846

3. Knowles WA, Pipkin P, Andrews N, Vyse A, Minor P, Brown DW, Miller E (2003) Population-based study of antibody to the human polyomaviruses BKV and JCV and the simian polyomavirus SV40. J Med Virol 71:115-123

4. Johnson EM, Wortman MJ, Dagdanova AV, Lundberg PS, Daniel DC (2013) Polyomavirus JC in the context of immunosuppression: a series of adaptive, DNA replication-driven recombination events in the development of progressive multifocal leukoencephalopathy. Clin Dev Immunol 2013:197807

5. White MK, Gordon J, Khalili K (2013) The rapidly expanding family of human polyomaviruses: recent developments in understanding their life cycle and role in human pathology. PLoS Pathog 9:e1003206

6. Berger JR, Aksamit AJ, Clifford DB, Davis L, Koralnik IJ, Sejvar JJ, Bartt R, Major EO, Nath A (2013) PML diagnostic criteria: consensus statement from the AAN Neuroinfectious Disease Section. Neurology 80:1430-1438

7. Chen Y, Trofe J, Gordon J, Du Pasquier RA, Roy-Chaudhury P, Kuroda MJ, Woodle ES, Khalili K, Koralnik IJ (2006) Interplay of cellular and humoral immune responses against BK virus in kidney transplant recipients with polyomavirus nephropathy. $\mathbf{J}$ Virol 80:3495-3505
8. Hariharan S, Cohen EP, Vasudev B, Orentas R, Viscidi RP, Kakela J, DuChateau B (2005) BK virus-specific antibodies and BKV DNA in renal transplant recipients with BKV nephritis. Am J Transplant 5:2719-2724

9. Mani J, Jin N, Schmitt M (2014) Cellular immunotherapy for patients with reactivation of JC and BK polyomaviruses after transplantation. Cytotherapy 16:1325-1335

10. Marshall LJ, Dunham L, Major EO (2010) Transcription factor Spi-B binds unique sequences present in the tandem repeat promoter/enhancer of JC virus and supports viral activity. J Gen Virol 91:3042-3052

11. Cortese I, Reich DS, Nath A (2021) Progressive multifocal leukoencephalopathy and the spectrum of JC virus-related disease. Nat Rev Neurol 17:37-51

12. Bowen LN, Smith B, Reich D, Quezado M, Nath A (2016) HIVassociated opportunistic CNS infections: pathophysiology, diagnosis and treatment. Nat Rev Neurol 12:662-674

13. Assetta B, Atwood WJ (2017) The biology of JC polyomavirus. Biol Chem 398:839-855

14. Committee UKCHCSS, Garvey L, Winston A, Walsh J, Post F, Porter K, Gazzard B, Fisher M, Leen C, Pillay D, Hill T, Johnson M, Gilson R, Anderson J, Easterbrook P, Bansi L, Orkin C, Ainsworth J, Phillips AN, Sabin CA (2011) HIV-associated central nervous system diseases in the recent combination antiretroviral therapy era. Eur J Neurol 18:527-534

15. Alstadhaug KB, Myhr KM, Rinaldo CH (2017) Progressive multifocal leukoencephalopathy. Tidsskr Nor Laegeforen 2017:137

16. Sano Y, Nakano Y, Omoto M, Takao M, Ikeda E, Oga A, Nakamichi K, Saijo M, Maoka T, Sano H, Kawai M, Kanda T (2015) Rituximab-associated progressive multifocal leukoencephalopathy derived from non-Hodgkin lymphoma: neuropathological findings and results of mefloquine treatment. Intern Med 54:965-970

17. Pavlovic D, Patera AC, Nyberg F, Gerber M, Liu M, Progressive Multifocal Leukeoncephalopathy C (2015) Progressive multifocal leukoencephalopathy: current treatment options and future perspectives. Ther Adv Neurol Disord 8:255-273

18. von Geldern G, Pardo CA, Calabresi PA, Newsome SD (2012) PML-IRIS in a patient treated with brentuximab. Neurology 79:2075-2077

19. Carson KR, Newsome SD, Kim EJ, Wagner-Johnston ND, von Geldern G, Moskowitz CH, Moskowitz AJ, Rook AH, Jalan P, Loren AW, Landsburg D, Coyne T, Tsai D, Raisch DW, Norris LB, Bookstaver PB, Sartor O, Bennett CL (2014) Progressive multifocal leukoencephalopathy associated with brentuximab vedotin therapy: a report of 5 cases from the Southern Network on Adverse Reactions (SONAR) project. Cancer 120:2464-2471

20. Clerico M, Artusi CA, Liberto AD, Rolla S, Bardina V, Barbero P, Mercanti SF, Durelli L (2017) Natalizumab in multiple sclerosis: long-term management. Int J Mol Sci 2017:18

21. Vermersch P, Kappos L, Gold R, Foley JF, Olsson T, Cadavid D, Bozic C, Richman S (2011) Clinical outcomes of natalizumabassociated progressive multifocal leukoencephalopathy. Neurology 76:1697-1704

22. Kappos L, Bates D, Edan G, Eraksoy M, Garcia-Merino A, Grigoriadis N, Hartung HP, Havrdova E, Hillert J, Hohlfeld R, Kremenchutzky M, Lyon-Caen O, Miller A, Pozzilli C, Ravnborg M, Saida T, Sindic C, Vass K, Clifford DB, Hauser S, Major EO, O'Connor PW, Weiner HL, Clanet M, Gold R, Hirsch HH, Radu EW, Sorensen PS, King J (2011) Natalizumab treatment for multiple sclerosis: updated recommendations for patient selection and monitoring. Lancet Neurol 10:745-758

23. Dong-Si T, Gheuens S, Gangadharan A, Wenten M, Philip J, McIninch J, Datta S, Richert N, Bozic C, Bloomgren G, Richman S, Weber T, Clifford DB (2015) Predictors of survival and functional outcomes in natalizumab-associated progressive multifocal leukoencephalopathy. J Neurovirol 21:637-644 
24. Dong-Si T, Richman S, Wattjes MP, Wenten M, Gheuens S, Philip J, Datta S, McIninch J, Bozic C, Bloomgren G, Richert N (2014) Outcome and survival of asymptomatic PML in natalizumabtreated MS patients. Ann Clin Transl Neurol 1:755-764

25. Wijburg MT, Kleerekooper I, Lissenberg-Witte BI, de Vos M, Warnke C, Uitdehaag BMJ, Barkhof F, Killestein J, Wattjes MP (2018) Association of progressive multifocal leukoencephalopathy lesion volume with JC virus polymerase chain reaction results in cerebrospinal fluid of natalizumab-treated patients with multiple sclerosis. JAMA Neurol 75:827-833

26. Monaco MC, Major EO (2015) Immune system involvement in the pathogenesis of JC virus induced PML: what is learned from studies of patients with underlying diseases and therapies as risk factors. Front Immunol 6:159

27. Maas RP, Muller-Hansma AH, Esselink RA, Murk JL, Warnke C, Killestein J, Wattjes MP (2016) Drug-associated progressive multifocal leukoencephalopathy: a clinical, radiological, and cerebrospinal fluid analysis of 326 cases. J Neurol 263:2004-2021

28. Clifford DB, Nath A, Cinque P, Brew BJ, Zivadinov R, Gorelik L, Zhao Z, Duda P (2013) A study of mefloquine treatment for progressive multifocal leukoencephalopathy: results and exploration of predictors of PML outcomes. J Neurovirol 19:351-358

29. De Luca A, Ammassari A, Pezzotti P, Cinque P, Gasnault J, Berenguer J, Di Giambenedetto S, Cingolani A, Taoufik Y, Miralles P, Marra CM, Antinori A, Gesida IASG (2008) Cidofovir in addition to antiretroviral treatment is not effective for AIDS-associated progressive multifocal leukoencephalopathy: a multicohort analysis. AIDS 22:1759-1767

30. Hall CD, Dafni U, Simpson D, Clifford D, Wetherill PE, Cohen B, McArthur J, Hollander H, Yainnoutsos C, Major E, Millar L, Timpone J (1998) Failure of cytarabine in progressive multifocal leukoencephalopathy associated with human immunodeficiency virus infection. AIDS Clinical Trials Group 243 Team. N Engl J Med 338:1345-1351

31. Jamilloux Y, Kerever S, Ferry T, Broussolle C, Honnorat J, Seve P (2016) Treatment of progressive multifocal leukoencephalopathy with mirtazapine. Clin Drug Investig 36:783-789

32. Bayer AL, Pugliese A, Malek TR (2013) The IL-2/IL-2R system: from basic science to therapeutic applications to enhance immune regulation. Immunol Res 57:197-209

33. Cayeux S, Meuer S, Pezzutto A, Korbling M, Haas R, Schulz R, Dorken B (1989) Allogeneic mixed lymphocyte reactions during a second round of ontogeny: normal accessory cells did not restore defective interleukin-2 (IL-2) synthesis in T cells but induced responsiveness to exogeneous IL-2. Blood 74:2278-2284

34. Moreno S, Miralles P, Diaz MD, Berenguer J, Bernaldo de Quiros JC, Blazquez R, Cosin J, Bouza E (1996) Cytarabine therapy for progressive multifocal leukoencephalopathy in patients with AIDS. Clin Infect Dis 23:1066-1068

35. Marriott PJ, O’Brien MD, Mackenzie IC, Janota I (1975) Progressive multifocal leucoencephalopathy: remission with cytarabine. J Neurol Neurosurg Psychiatry 38:205-209

36. Przepiorka D, Jaeckle KA, Birdwell RR, Fuller GN, Kumar AJ, Huh YO, McCutcheon I (1997) Successful treatment of progressive multifocal leukoencephalopathy with low-dose interleukin-2. Bone Marrow Transplant 20:983-987

37. Buckanovich RJ, Liu G, Stricker C, Luger SM, Stadtmauer EA, Schuster SJ, Duffy K, Tsai D, Pruitt A, Porter DL (2002) Nonmyeloablative allogeneic stem cell transplantation for refractory Hodgkin's lymphoma complicated by interleukin-2 responsive progressive multifocal leukoencephalopathy. Ann Hematol 81:410-413

38. Kunschner L, Scott TF (2005) Sustained recovery of progressive multifocal leukoencephalopathy after treatment with IL-2. Neurology $65: 1510$
39. Mahler C, Andrews M, Henson SM, Gnanapavan S (2020) Sequential interleukin 2 and pembrolizumab use in progressive multifocal leukoencephalopathy. Neurol Neuroimmunol Neuroinflamm 2020:7

40. Dubey D, Zhang Y, Graves D, DeSena AD, Frohman E, Greenberg B (2016) Use of interleukin-2 for management of natalizumab-associated progressive multifocal leukoencephalopathy: case report and review of literature. Ther Adv Neurol Disord 9:211-215

41. Guffroy A, Solis M, Gies V, Dieudonne Y, Kuhnert C, Lenormand C, Kremer L, Molitor A, Carapito R, Hansmann Y, Poindron V, Martin T, Hirschi S, Korganow AS (2020) Progressive multifocal leukoencephalopathy and sarcoidosis under interleukin 7: the price of healing. Neurol Neuroimmunol Neuroinflamm 2020:7

42. Harel A, Horng S, Gustafson T, Ramineni A, Farber RS, Fabian M (2018) Successful treatment of progressive multifocal leukoencephalopathy with recombinant interleukin-7 and maraviroc in a patient with idiopathic CD4 lymphocytopenia. J Neurovirol 24:652-655

43. Alstadhaug KB, Croughs T, Henriksen S, Leboeuf C, Sereti I, Hirsch HH, Rinaldo CH (2014) Treatment of progressive multifocal leukoencephalopathy with interleukin 7. JAMA Neurol 71:1030-1035

44. Guille M, Rousset S, Bonneville F, Mengelle C, Taoufik Y, Delobel P, Martin-Blondel G (2019) IL-7 immunotherapy for progressive multifocal leukoencephalopathy in a patient with already controlled HIV-1 infection on antiretroviral therapy. AIDS 33:1954-1956

45. Gasnault J, de-Goer-de-Herve MG, Michot JM, Hendel-Chavez H, Seta V, Mazet AA, Croughs T, Stankoff B, Bourhis JH, Lambotte O, Delfraissy JF, Taoufik Y (2014) Efficacy of recombinant human interleukin 7 in a patient with severe lymphopenia-related progressive multifocal leukoencephalopathy. Open Forum Infect Dis 1:ofu074

46. Miskin DP, Chalkias SG, Dang X, Bord E, Batson S, Koralnik IJ (2016) Interleukin-7 treatment of PML in a patient with idiopathic lymphocytopenia. Neurol Neuroimmunol Neuroinflamm 3:e213

47. Soleimani-Meigooni DN, Schwetye KE, Angeles MR, Ryschkewitsch CF, Major EO, Dang X, Koralnik IJ, Schmidt RE, Clifford DB, Kuhlmann FM, Bucelli RC (2017) JC virus granule cell neuronopathy in the setting of chronic lymphopenia treated with recombinant interleukin-7. J Neurovirol 23:141-146

48. Sospedra M, Schippling S, Yousef S, Jelcic I, Bofill-Mas S, Planas R, Stellmann JP, Demina V, Cinque P, Garcea R, Croughs T, Girones R, Martin R (2014) Treating progressive multifocal leukoencephalopathy with interleukin 7 and vaccination with JC virus capsid protein VP1. Clin Infect Dis 59:1588-1592

49. Patel A, Patel J, Ikwuagwu J (2010) A case of progressive multifocal leukoencephalopathy and idiopathic CD4+ lymphocytopenia. J Antimicrob Chemother 65:2697-2698

50. Schonrich G, Raftery MJ (2019) The PD-1/PD-L1 axis and virus infections: a delicate balance. Front Cell Infect Microbiol 9:207

51. Beck ES, Cortese I (2020) Checkpoint inhibitors for the treatment of JC virus-related progressive multifocal leukoencephalopathy. Curr Opin Virol 40:19-27

52. Cortese I, Muranski P, Enose-Akahata Y, Ha SK, Smith B, Monaco M, Ryschkewitsch C, Major EO, Ohayon J, Schindler MK, Beck E, Reoma LB, Jacobson S, Reich DS, Nath A (2019) Pembrolizumab Treatment for Progressive Multifocal Leukoencephalopathy. N Engl J Med 380:1597-1605

53. Kupper C, Heinrich J, Kamm K, Bucklein V, Rothenfusser S, Straube A (2019) Pembrolizumab for progressive multifocal leukoencephalopathy due to primary immunodeficiency. Neurol Neuroimmunol Neuroinflamm 6:e628 
54. Hoang E, Bartlett NL, Goyal MS, Schmidt RE, Clifford DB (2019) Progressive multifocal leukoencephalopathy treated with nivolumab. J Neurovirol 25:284-287

55. Rauer S, Marks R, Urbach H, Warnatz K, Nath A, Holland S, Weiller C, Grimbacher B (2019) Treatment of progressive multifocal leukoencephalopathy with pembrolizumab. N Engl J Med 380:1676-1677

56. Goereci Y, Schweitzer F, Wellstein A, Silling S, Borchmann S, von Tresckow B, Adams O, Martin R, Schlamann M, Schroeter M, Fink GR, Wattjes MP, Warnke C (2020) Clearance of JC polyomavirus from cerebrospinal fluid following treatment with interleukin-2 and pembrolizumab in an individual with progressive multifocal leukoencephalopathy and no underlying immune deficiency syndrome. Eur J Neurol 27:2375-2377

57. Stogbauer J, Schulz-Schaeffer W, Muhl-Benninghaus R, Lochner $\mathrm{P}$ (2021) Clinical and magnetic resonance imaging monitoring in progressive multifocal leukoencephalopathy treated with pembrolizumab: a case report. Neurol Sci 42:357-359

58. Kapadia RK, Ney D (2020) Stabilization of progressive multifocal leukoencephalopathy after pembrolizumab treatment. Neurohospitalist 10:238-239

59. Mozo Ruiz M, Rosado Barrasa N, Tena Gomez D, Gonzalez T, de Suso M (2020) Pembrolizumab treatment for progressive multifocal leukoencephalopathy in a patient with human immunodeficiency virus infection. Enferm Infecc Microbiol Clin 38:396-397

60. Grassl N, Bunse L, Beutel T, Klockziem M, Gass A, Platten M, Eisele P (2020) Nivolumab for treatment of progressive multifocal leukoencephalopathy in Sezary syndrome. Eur J Neurol 27:2373-2374

61. Audemard-Verger A, Gasnault J, Faisant M, Besse MC, MartinSilva N, Berra M, Fournier L, Boutemy J, Maigne G, De Boysson H, Ruet A, Vabret A, Chapon F, Martin-Blondel G, Aouba A (2019) Sustained response and rationale of programmed cell death-1-targeting for progressive multifocal leukoencephalopathy. Open Forum Infect Dis 6:ofz374

62. Uzunov M, Demeret S, Nguyen-Quoc S, Morel V, Bellanger A, Chavez H, Gasnault J, Leblond V, Roos-Weil D (2020) Postallogeneic transplantation progressive multifocal leukoencephalopathy successfully treated by nivolumab. Br J Haematol 188:e82-e84

63. Walter O, Treiner E, Bonneville F, Mengelle C, Vergez F, Lerebours F, Delobel P, Liblau R, Martin-Blondel G, Immune Checkpoint Inhibitors in PMLSG (2019) Treatment of progressive multifocal leukoencephalopathy with nivolumab. N Engl J Med 380:1674-1676

64. Holmes A, Wellings T, Walsh O, Rowlings P (2020) Progressive multifocal leukoencephalopathy associated with a lymphoproliferative disorder treated with pembrolizumab. J Neurovirol 26:961-963

65. Roos-Weil D, Weiss N, Guihot A, Uzunov M, Bellanger A, Eymard B, Saadoun D, Houillier C, Idbaih A, Demeret S, Deback C, Leblond V, Galanaud D, Shor N, Pourcher V (2021) Immune checkpoint inhibitors for progressive multifocal leukoencephalopathy: a new gold standard? J Neurol 268:2458-2465

66. Mohn N, Wattjes MP, Adams O, Nay S, Tkachenko D, Salge F, Heine J, Pars K, Hoglinger G, Respondek G, Stangel M, Skripuletz T, Jacobs R, Suhs KW (2021) PD-1-inhibitor pembrolizumab for treatment of progressive multifocal leukoencephalopathy. Ther Adv Neurol Disord 14:1756286421993684

67. Yousef S, Planas R, Chakroun K, Hoffmeister-Ullerich S, Binder TM, Eiermann TH, Martin R, Sospedra M (2012) TCR bias and HLA cross-restriction are strategies of human brain-infiltrating $\mathrm{JC}$ virus-specific CD4+ T cells during viral infection. J Immunol 189:3618-3630

68. Pawlitzki M, Schneider-Hohendorf T, Rolfes L, Meuth SG, Wiendl H, Schwab N, Grauer OM (2019) Ineffective treatment of
PML with pembrolizumab: Exhausted memory T-cell subsets as a clue? Neurol Neuroimmunol Neuroinflamm 6:e627

69. Martinot M, Ahle G, Petrosyan I, Martinez C, Gorun DM, Mohseni-Zadeh M, Fafi-Kremer S, Tebacher-Alt M (2018) Progressive multifocal leukoencephalopathy after treatment with nivolumab. Emerg Infect Dis 24:1594-1596

70. Mohn N, Beutel G, Gutzmer R, Ivanyi P, Satzger I, Skripuletz T (2019) Neurological immune related adverse events associated with nivolumab, ipilimumab, and pembrolizumab therapy-review of the literature and future outlook. J Clin Med 2019:8

71. Kumar V, Chaudhary N, Garg M, Floudas CS, Soni P, Chandra AB (2017) Current diagnosis and management of immune related adverse events (irAEs) induced by immune checkpoint inhibitor therapy. Front Pharmacol 8:49

72. Kharfan-Dabaja MA, Ayala E, Greene J, Rojiani A, Murtagh FR, Anasetti C (2007) Two cases of progressive multifocal leukoencephalopathy after allogeneic hematopoietic cell transplantation and a review of the literature. Bone Marrow Transplant 39:101-107

73. Hirsch HH, Kardas P, Kranz D, Leboeuf C (2013) The human JC polyomavirus (JCPyV): virological background and clinical implications. APMIS 121:685-727

74. Smith CA, Ng CY, Heslop HE, Holladay MS, Richardson S, Turner EV, Loftin SK, Li C, Brenner MK, Rooney CM (1995) Production of genetically modified Epstein-Barr virus-specific cytotoxic $\mathrm{T}$ cells for adoptive transfer to patients at high risk of EBV-associated lymphoproliferative disease. J Hematother 4:73-79

75. O'Reilly RJ, Small TN, Papadopoulos E, Lucas K, Lacerda J, Koulova L (1997) Biology and adoptive cell therapy of EpsteinBarr virus-associated lymphoproliferative disorders in recipients of marrow allografts. Immunol Rev 157:195-216

76. Walter EA, Greenberg PD, Gilbert MJ, Finch RJ, Watanabe KS, Thomas ED, Riddell SR (1995) Reconstitution of cellular immunity against cytomegalovirus in recipients of allogeneic bone marrow by transfer of T-cell clones from the donor. N Engl J Med 333:1038-1044

77. Cobbold M, Khan N, Pourgheysari B, Tauro S, McDonald D, Osman H, Assenmacher M, Billingham L, Steward C, Crawley C, Olavarria E, Goldman J, Chakraverty R, Mahendra P, Craddock C, Moss PA (2005) Adoptive transfer of cytomegalovirusspecific CTL to stem cell transplant patients after selection by HLA-peptide tetramers. J Exp Med 202:379-386

78. Kaeuferle T, Krauss R, Blaeschke F, Willier S, Feuchtinger T (2019) Strategies of adoptive T -cell transfer to treat refractory viral infections post allogeneic stem cell transplantation. J Hematol Oncol 12:13

79. Balduzzi A, Lucchini G, Hirsch HH, Basso S, Cioni M, Rovelli A, Zincone A, Grimaldi M, Corti P, Bonanomi S, Biondi A, Locatelli F, Biagi E, Comoli P (2011) Polyomavirus JC-targeted T-cell therapy for progressive multiple leukoencephalopathy in a hematopoietic cell transplantation recipient. Bone Marrow Transplant 46:987-992

80. Muftuoglu M, Olson A, Marin D, Ahmed S, Mulanovich V, Tummala S, Chi TL, Ferrajoli A, Kaur I, Li L, Champlin R, Shpall EJ, Rezvani K (2018) Allogeneic BK virus-specific T cells for progressive multifocal leukoencephalopathy. N Engl J Med 379:1443-1451

81. Krymskaya L, Sharma MC, Martinez J, Haq W, Huang EC, Limaye AP, Diamond DJ, Lacey SF (2005) Cross-reactivity of $\mathrm{T}$ lymphocytes recognizing a human cytotoxic T-lymphocyte epitope within BK and JC virus VP1 polypeptides. J Virol 79:11170-11178

82. Hopfner F, Mohn N, Eiz-Vesper B, Maecker-Kolhoff B, Gottlieb J, Blasczyk R, Mahmoudi N, Pars K, Adams O, Stangel M, Wattjes MP, Hoglinger G, Skripuletz T (2021) Allogeneic BK 
virus-specific T-cell treatment in 2 patients with progressive multifocal leukoencephalopathy. Neurol Neuroimmunol Neuroinflamm 2021:8

83. Wicklein R, Heidegger S, Verbeek M, Eiz-Vesper B, MaeckerKolhoff B, Kirschke JS, Page A, Korn T, Hemmer B, Deschauer M (2021) Combined treatment with pembrolizumab and allogenic BK virus-specific $\mathrm{T}$ cells in progressive multifocal leukoencephalopathy: a case report. Neurol Neuroimmunol Neuroinflamm 2021:8

84. Cortese I, Beck ES, Al-Louzi O, Ohayon J, Andrada F, Osuorah I, Dwyer J, Billioux BJ, Dargah-Zada N, Schindler MK, Binder K, Reoma L, Norato G, Enose-Akahata Y, Smith BR, Monaco MC, Major EO, Jacobson S, Stroncek D, Highfill S, Panch S, Reich DS, Barrett J, Nath A, Muranski P (2021) BK virus-specific T cells for immunotherapy of progressive multifocal leukoencephalopathy: an open-label, single-cohort pilot study. Lancet Neurol 20:639-652
85. Steinhardt MJ, Wiercinska E, Pham M, Grigoleit GU, Mazzoni A, Da-Via M, Zhou X, Meckel K, Nickel K, Duell J, Krummenast FC, Kraus S, Hopkinson C, Weissbrich B, Mullges W, Stoll G, Kortum KM, Einsele H, Bonig H, Rasche L (2020) Progressive multifocal leukoencephalopathy in a patient post allo-HCT successfully treated with JC virus specific donor lymphocytes. J Transl Med 18:177

86. Berzero G, Basso S, Stoppini L, Palermo A, Pichiecchio A, Paoletti M, Lucev F, Gerevini S, Rossi A, Vegezzi E, Diamanti L, Bini P, Gastaldi M, Delbue S, Perotti C, Seminari E, Faraci M, Luppi M, Baldanti F, Zecca M, Marchioni E, Comoli P (2021) Adoptive transfer of JC virus-specific T lymphocytes for the treatment of progressive multifocal leukoencephalopathy. Ann Neurol 89:769-779 